\title{
Analysis of the Layer Farm Business on BUMDes "Mandiri”" and Breeder Partnersin Babakan Bogor Village Kabawetan Subdistrict Kepahiang District
}

\author{
A. Martini and N. N. Arianti \\ Department of Social Economic of Agriculture, Faculty of Agriculture, University of Bengkulu \\ Corresponding Author: nnarianti@unib.ac.id
}

\begin{abstract}
This study aims to analyze the income of the BUMDes "Mandiri" layer chicken farm and partner farms, as well as the size of the income earned by BUMDes "Mandiri" and breeder partners from the profit-sharing system carried out together. The research respondents were the BUMDes "Mandiri" farm manager and two breeder partners. Operating income is calculated by finding the difference between business revenues and total business costs incurred. The share received by BUMDes "Mandiri" and partner farmers from partner farm income is determined based on the percentage agreed in the partnership agreement, namely $51 \%$ for BUMDes "Mandiri" and $49 \%$ for breeder partners. The results showed that the income of the BUMDes "Mandiri" livestock business in one month was Rp. 3,668,890.00 or Rp. 3,668.89/head, while the partner's husbandry business income was Rp. $6,404,505.00$ or Rp. $12,809.00 /$ head. The portion of the partner's husbandry business income that belongs to BUMDes "Mandiri" is Rp. 3,266,295.00/month and that which belongs to breeder partners is Rp. $3,138,210.00 /$ month.
\end{abstract}

Key words: layer chicken business analysis, BUMDes "Mandiri”, breeder partners

\section{INTRODUCTION}

Badan Usaha Milik Desa (BUMDes) are village business institutions managed by the village government as well as village communities to strengthen the village economy and formed based on the needs and potentials that exist in the village. BUMDes is a business entity that can help the community in everything, including meeting daily needs, becoming business opportunities or employment opportunities, adding insight to the village community.

According to the Government Regulation of the Republic of Indonesia Number 43 of 2014 concerning Implementing Regulations of Law Number 6 of 2014 concerning Villages in Article 1 number 7, Badan Usaha Milik Desa are business entities whose capital is wholly or most of the capital owned by the village through direct participation originating from the village. separated village assets to manage assets, services, and other businesses for the greatest welfare of the village community. BUMDes is a village business formed or established by the village government whose capital ownership and management are carried out by the village government and the community. BUMDes aims to improve the economic welfare of residents through the development of rural community economic enterprises following the potential of each village. BUMDes are developed according to their potential so that the types of businesses vary, such as grocery stores, village mini markets, rental of building project tools, and other types of business services including tourist villages (https://peraturan.bpk.go.id ., 2017).

BUMDes is a pillar of village economic activity that functions as a social and commercial institution. BUMDes as a social institution sided with the interests of the community through the provision of social services. Meanwhile, as a commercial institution, BUMDes can seek profit through local resource offerings (goods and services). BUMDes as a legal entity was formed based on the applicable laws and regulations and following the agreements that were built in the village community. Thus, the form of BUMDes can vary in each village according to local characteristics, potential, and resources. BUMDes is further regulated through Regional Regulations. Data from Kementrian Desa Pembangunan Daerah Tertinggal dan Transmigrasi, shows that 41,000 BUMDes have developed in 74,957 villages in Indonesia. BUMDes in Bengkulu Province lags in Java, which has already developed BUMDes. Data from Dinas Pemberdayaan Masyarakat dan Desa shows that BUMDes in Bengkulu Province only developed in 2016 and there are 1,032 BUMDes activity units spread over 1,341 villages. The number of BUMDes and their level of activeness ratio in Bengkulu Province are presented in Table 1 (Sari and Ekaputri, 2019). 
Table 1. Number of BUMDes and the ratio of activeness in the Province of Bengkulu 2018

\begin{tabular}{|c|c|c|c|c|c|c|}
\hline Districts & $\begin{array}{l}\text { Number of } \\
\text { Districts }\end{array}$ & $\begin{array}{l}\text { Number } \\
\text { of } \\
\text { Villages }\end{array}$ & $\begin{array}{l}\text { Number of } \\
\text { BUMDes }\end{array}$ & $\begin{array}{c}\text { Active } \\
\text { BUMDes }\end{array}$ & $\begin{array}{c}\text { Ratio of } \\
\text { village- } \\
\text { BUMDes }(\%)\end{array}$ & $\begin{array}{c}\text { Ratio of } \\
\text { Active } \\
\text { BUMDes }(\%)\end{array}$ \\
\hline Bengkulu Selatan & 11 & 142 & 131 & 118 & 92 & 90 \\
\hline Rejang Lebong & 14 & 122 & 122 & 62 & 100 & 51 \\
\hline North Bengkulu & 19 & 215 & 115 & 87 & 53 & 76 \\
\hline Kaur & 15 & 192 & 64 & 48 & 33 & 75 \\
\hline Seluma & 13 & 182 & 153 & 92 & 84 & 60 \\
\hline Muko-Muko & 15 & 148 & 126 & 99 & 85 & 79 \\
\hline Lebong & 12 & 93 & 79 & 14 & 85 & 18 \\
\hline Kepahiang & 8 & 105 & 105 & 100 & 100 & 95 \\
\hline Bengkulu Tengah & 10 & 142 & 137 & 102 & 96 & 74 \\
\hline Total of & 117 & 1341 & 1.032 & 722 & 77 & 70 \\
\hline
\end{tabular}

Source: Community and Village Empowerment Service, Bengkulu Province (2018) in Sari and Ekaputri (2019).

The BUMDes "Mandiri" in Babakan Bogor Village, Kabawetan District is one of the active BUMDes in Kepahiang Regency. BUMDes "Mandiri" has three business units that are running well, namely laying hens, beauty salons, and BNI link. The laying hens farming business is BUMDes "Mandiri" program that has been running actively and productively. The development of livestock business provides a real contribution and has strategic value, namely meeting the animal protein needs of the community and providing job opportunities.

The purpose of the BUMDes "Mandiri" program for laying hens is, among other things, to improve the welfare of the community, therefore the BUMDes "Mandiri" develops a layer of chicken farming business by partnering with the village community. The partnership pattern used by BUMDes "Mandiri" is a profit-sharing partnership pattern (adoptive father) where this partnership system is more of assistance from BUMDes "Mandiri" to partner farmers. BUMDes "Mandiri" only provides laying hens while other production facilities, livestock cultivation management processes, and product marketing are left to breeder partners. BUMDes "Mandiri" gets a share of $51 \%$ of the income earned by partner farmers every month for 12 months. The payback period for partner farmers is from the time the agreement is agreed upon and signed by both parties.

The management of laying hens between BUMDes "Mandiri" and breeder partners with various strengths and weaknesses of each certainly affects the income received by farmers. Based on this, this study aims to analyze: 1) The income of the BUMDes "Mandiri" layer chicken farm and partner farms, and 2) The amount of income earned by the BUMDes "Mandiri" and breeder partners from the profit-sharing system.

\section{RESEARCH METHODS}

The research was carried out in January 2020 in Babakan Bogor Village, Kabawetan District, Kepahiang Regency. The location selection was done deliberately with the consideration that BUMDes "Mandiri" is a BUMDes that actively manages layer chicken farms with a business scale of 2,000 heads consisting of 1,000 heads managed by BUMDes "Mandiri" and 1,000 heads managed by two breeder partners.

The data of this research are primary as well as secondary data. Primary data were obtained from direct observations and interviews with the Director of BUMDes, "Mandiri", BUMDes farm managers, and partner farmers. Secondary data is data that comes from the literature and other references related to the research topic.

\section{Income Analysis}

The business analysis is carried out in units of IDR/chicken so that performance comparisons can be made between the livestock businesses carried out by BUMDes 'Mandiri' and breeder partners because of the number of chickens cultivated by BUMDes "Mandiri" and breeder partners is different. The income analysis of laying hens is carried out using the following formula: (Suratiyah, 2016). 


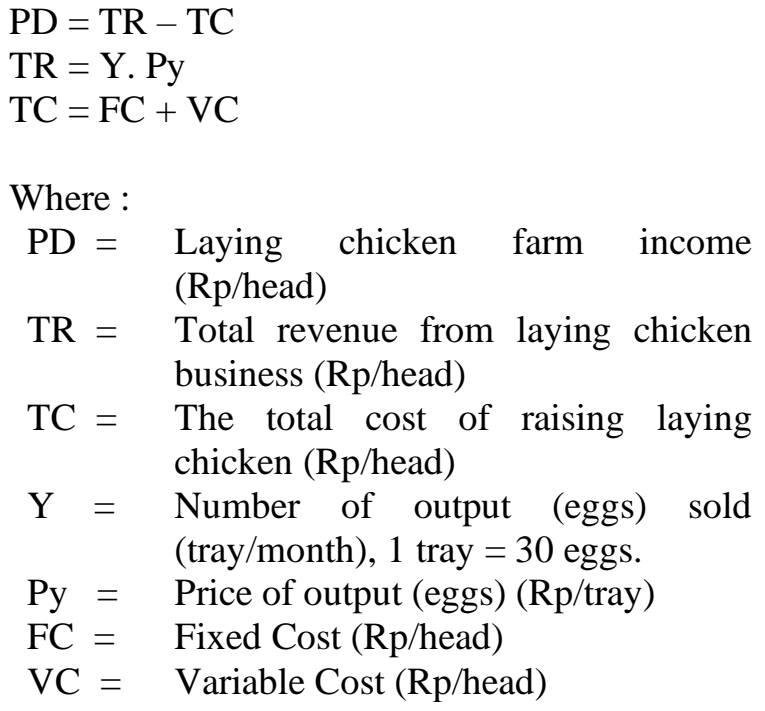

Barokah et al (2016) also use the method of calculating operating income by subtracting revenues from costs. The total cost of business is the sum of the total fixed costs and the total variable costs.

\section{Profit-Sharing System Analysis}

BUMDes "Mandiri" cooperates with partner farmers so that the benefits of the establishment of BUMDes "Mandiri" can be felt by farmers in Babakan Bogor Village. The form of cooperation carried out by BUMDes "Mandiri" with breeder partners is the provision of capital for the procurement of laying hens. BUMDes "Mandiri" is not involved in operational activities. The profit-sharing method is $51 \%$ for BUMDes "Mandiri" and $49 \%$ for partner farmers within a period of 12 months. The profit-sharing system was analyzed descriptively.

\section{RESULTS AND DISCUSSION}

\section{Characteristics of Breeder}

The characteristics of farmer managing BUMDes "Mandiri" farm and partner farmers are presented in Table 2. Farmers who are of productive age are in the age range of 15-64 years. A productive age will provide productive work results (large income) because they still have a strong spirit and energy in managing their business so that maximum results will be obtained. The average age of breeders who run laying hens at BUMDes "Mandiri" and breeder partners is 31.3 years, meaning that physically and mentally they can work optimally in managing their livestock business.

The laying chicken farming business at BUMDes "Mandiri" was established in 2018, so the business experience of the head of the BUMDes "Mandiri" unit is as per the age of the broilers being reared, which is 24 months in business experience. While the business experience of breeder partners is for 8 months according to the age of the chickens they maintain.

The formal education of laying hens breeders of BUMDes "Mandiri" and breeder partners is for 12 years, meaning that the breeder has a high school education level so that it is categorized as quite good. Education is an important thing for someone is doing a job/business because education affects the knowledge and level of adoption of breeder innovations related to laying hens so that the opportunity to increase the scale of laying hens is more open. With previous education, of course, farmers can read and count which will make it easier to increase their business and be able to think rationally in running their livestock business. Before starting the laying hens business, the head of the BUMDes "Mandiri" unit and breeder partners also received theoretical and practical training on how to raise layer chickens which were held in Bengkulu City for 2 weeks. Average of family member is 4 people. The number of family members who are dependents of farmers will motivate the farmers to strive and improve their livestock business.

Table 2. Characteristics breeder chicken race laying BUMDes "Mandiri"

\begin{tabular}{llcccc}
\hline \multicolumn{1}{c}{ Name } & \multicolumn{1}{c}{ Status } & $\begin{array}{c}\text { Age } \\
\text { (Years) }\end{array}$ & $\begin{array}{c}\text { Experience } \\
\text { in Business } \\
\text { (Months) }\end{array}$ & $\begin{array}{c}\text { Level of } \\
\text { Education }\end{array}$ & Family Members \\
\hline Nendik & Breeder BUMDes & 27 & 24 & High school & 3 \\
Sutrisno & Breeder Partner & 35 & 8 & High school & 4 \\
Sugiarto & Breeder Partner & 32 & 8 & High school & 4 \\
\hline Average & & 31.3 & 13.3 & High school & 4 \\
\hline
\end{tabular}

Source: Primary Data Processed, 2020 
The existence of a strong enough motivation will affect the desire of farmers to get maximum results to meet the needs of the family. The number of dependents of this family is closely related to the economic burden borne by chicken farmers. The more the number of family dependents, the higher the motivation of farmers to work so that the income received by laying hens breeders is also higher.

\section{Income Analysis}

Laying chicken breeders BUMDes "Mandiri" and breeder partners started their business by buying laying hens that were 17 weeks old from a seedling shop. BUMDes "Mandiri" purchased 1,000 laying hens in 2018 for a cage with an area of $128 \mathrm{~m}^{2}$. The price of seeds is Rp. 68,000.00/head, so the cost of seeds is Rp. 68,000,000,00. In 2019, the BUMDes "Mandiri" purchased 1,000 chicken seeds for Rp. 76,000.00/head (total cost of Rp. 76,000,000.00) which was then handed over to the two breeders' partners for maintenance. Each of them obtained 500 chickens for a caged area of $50 \mathrm{~m}^{2}$ each.

\section{Fixed Cost}

Fixed costs are costs incurred by laying chicken farms of BUMDes "Mandiri" and breeder partners, that do not run out in one production period. The size of the production cost is not influenced by the number of products produced. Fixed costs consist of depreciation costs for laying hens, cage depreciation, equipment depreciation, land rent or tax, depreciation, and vehicle tax (Table 3). The cost of depreciation of chickens for a month with the final value which is equivalent to the price of rejected chickens is $\mathrm{Rp}$. 35,000.00/head. The average depreciation of broilers at BUMDes "Mandiri" and partner farms for one month was Rp. 1,269,231/head (47.70\%) and Rp. 1,576,924/head (65.86\%). The difference in the cost of chicken depreciation is caused by the difference in the purchase price of the seeds.

Table 3. Average fixed cost of laying chicken farming business BUMDes "Mandiri" and breeder partners in one month

\begin{tabular}{llrrrr}
\hline \multirow{2}{*}{ No. } & \multicolumn{2}{c}{ Description } & \multicolumn{2}{c}{ BUMDes "Mandiri" } & \multicolumn{2}{c}{ Breeder partners } \\
\cline { 2 - 6 } & & Rp/head & $\%$ & Rp/head & $\%$ \\
\hline 1. & Depreciation of chicken & $1,269.23$ & 47.70 & $1,576.92$ & 65.86 \\
2. & Depreciation of cage & 625.00 & 27.10 & 541.67 & 28.11 \\
3. & Shrinkage of the tool & 80.78 & 3.50 & 75.67 & 3.63 \\
4. & Depreciation of the vehicle & 0.00 & 0.00 & 11.11 & 0.64 \\
5. & Rent and land tax & 500.00 & 21.70 & 3.75 & 0.16 \\
6. & Vehicle tax & 0.00 & 0.00 & 31.08 & 1.59 \\
\hline \multicolumn{2}{l}{ Total Cost Fixed } & $2,475.01$ & 100.00 & $2,240.19$ & 100.00 \\
\hline
\end{tabular}

Source: Primary Data Processed, 2020

The cost of cage depreciation on BUMDes "Mandiri" with a cage size of $128 \mathrm{~m}^{2}$ for one month was Rp. 625.00/head (27.10\%), on partner farms with a cage size of $50 \mathrm{~m}^{2}$ is $\mathrm{Rp}$. 541,668/head (28.11\%). BUMDes "Mandiri" farms and partner farms have types of equipment including feeders, speakers, buckets, sprayers, water reservoirs/plastic drums, water pumping machines, shovels, feed scales, scissors, water faucets, water pipes/hoses, and broomsticks. The average depreciation cost of livestock business equipment by BUMDes "Mandiri" and breeder partners was Rp. 80,782/head (3.50\%) and Rp. $75,656 /$ head (3.63\%), respectively.

The average fixed costs incurred in BUMDes "Mandiri" are higher than breeder partners. The components of fixed costs with a higher percentage of contribution to the BUMDes "Mandiri" business compared to breeder partners' businesses are chicken depreciation, cage depreciation, and land rent or tax.

\section{Variable Cost}

Variable costs are the costs that are highly dependent on the scale of production. Variable costs include feed costs, vaccine and vitamin costs, packaging costs, labor costs, fuel costs, and electricity costs. The average variable costs of laying chicken farms for BUMDes "Mandiri" and breeder partners are presented in Table 4.

The average total variable cost issued on the farm BUMDes "Mandiri" is high compared to the effort of the breeder partners. The biggest cost of the component incurred is the cost of feed, i.e. around $80 \%$ of the total variables cost. The nutrition should be regularly given to the chicken in the amount that is enough because it affects the productivity of the chicken. The price of feed strongly affects the amount of feed that is given. 
Table 4. Average variable costs in BUMDes "Mandiri" layer chicken farms and breeder partner in one month

\begin{tabular}{llrrrr}
\hline \multirow{2}{*}{ No. } & \multicolumn{1}{c}{ Description } & \multicolumn{2}{c}{ BUMDes "Mandiri" } & \multicolumn{2}{c}{ Breeder partners } \\
\cline { 2 - 6 } & \multicolumn{2}{c}{$($ Rp/head $)$} & $(\%)$ & $($ Rp/head $)$ & $(\%)$ \\
\hline 1 & Cost of feed & $22,077.00$ & 82.0 & $20,955.00$ & 84.6 \\
2 & Cost of medicines (Vaccines & 967.50 & 3.6 & 945.00 & 3.9 \\
& and vitamins) & & & 760.80 & 3.0 \\
3 & Cost of packaging & 684.60 & 2.5 & $1,450.00$ & 5.9 \\
4 & Cost of labor & $2,250.00$ & 8.4 & 540.00 & 2.1 \\
5 & Cost of fuel & 840.00 & 3.1 & 100.00 & 0.5 \\
6 & Cost of electricity & 75.00 & 0.3 & $24,750.80$ & 100.0 \\
7 & Total variable costs & $26,894.10$ & 100.0 & & \\
\hline
\end{tabular}

Source: Primary Data Processed, 2020

According to Murib et al (2014) feed prices are cheap and the availability is assured with increasing the production of eggs.

\section{Total Cost}

Total cost is the sum of fixed costs and variable costs. The total cost of business can be seen in Table 5. The average total cost incurred by BUMDes "Mandiri" is also higher than the business of the breeder partner. BUMDes
"Mandiri" must rent land to establish their livestock business, while the partner does not need to rent land to set up their livestock business because they have empty land for cages. In addition, BUMDes "Mandiri" also does not have an operational vehicle to market their egg production, so they have to rent a vehicle and incur considerable costs compared to breeder partners who already have their operational vehicle.

Table 5. The average total cost of laying chicken farming business BUMdes "Mandiri" and breeder partners in one month

\begin{tabular}{llcc}
\hline No & \multicolumn{1}{c}{ Description } & $\begin{array}{c}\text { BUMDes “Mandiri” } \\
(\mathrm{Rp} / \mathrm{head})\end{array}$ & $\begin{array}{c}\text { Breeder partners } \\
(\mathrm{Rp} / \mathrm{head})\end{array}$ \\
\hline 1 & Total variable costs & $26,894.10$ & $24,750.80$ \\
2 & Total fixed costs & $2,475.01$ & $2,240.19$ \\
3 & Total cost & $29,369.11$ & $26,990.99$ \\
\hline
\end{tabular}

Source: Primary Data Processed, 2020

The variable costs incurred by BUMDes "Mandiri" are also higher in terms of feed, labor, and fuel costs. BUMDes "Mandiri" uses $325 \mathrm{~S}$ and $325 \mathrm{R}$ brand feed while partner farmers use TQ 93 brand feed which is cheaper. The labor costs applied by BUMDes "Mandiri" and breeder partners are the same but there is a difference in timing, wherein BUMDes "Mandiri" the night watchman works for 10 hours, while the breeder partners only work for 1 hour.

\section{Total Revenue}

The revenue from the BUMDes "Mandiri" farm business and breeder partners comes from the sale of the main product, namely chicken eggs and by-products in the form of chicken manure (Table 6). The revenue from laying hens in one month BUMDes "Mandiri" and breeder partners is Rp. 33,038.00/head and Rp. $39,800.00 /$ head. The income from the business of BUMDes "Mandiri" breeders is smaller than that of breeder partners due to the lower productivity of BUMDes "Mandiri" laying hens because 400 chickens have entered the reject stage. In addition, there is also a difference in the selling price of chicken eggs, where BUMDes "Mandiri" sells eggs at Rp. 38,000.00/tray while partnering breeders at a. price of Rp. 40,000.00/tray. The selling price of eggs from breeder partners is more expensive because the size of the eggs is larger. After all, the age of the chickens is still more productive than the BUMDes "Mandiri" business. The high productivity of partner farms is because the chickens are still in their fertile period. Chicken productivity will decrease if it approaches the age of rejection (Nawawi et al, 2017).

The laying hens reared in BUMDes "Mandiri" and breeder partners are brown laying hens (Hisex Brown) which are in the layering phase. Laying hens that are in the layer phase are adult chickens that are undergoing a period of laying or producing eggs (Purwaningsih, 2014). 
Table 6. Average revenue for laying chicken farming BUMDes "Mandiri" and breeder partners in one month

\begin{tabular}{llrr}
\hline No. & Items & BUMDes "Mandiri" & Breeder partners \\
\hline 1 & Chicken Egg & & \\
& a. Quantity (Item) & 25,230 & 14,520 \\
& b. Quantity (Tray) & 841 & 484 \\
& c. Price (Rp/tray) & $38,000.00$ & $40,000.00$ \\
& Revenue (Rp) & $31,958,000.00$ & $19,360,000.00$ \\
2 & Chicken Manure & 1,200 & 600 \\
& a. Quantity (Kg) & 900.00 & 900.00 \\
& b. Price (Rp/Kg) & $1,080,000.00$ & $540,000.00$ \\
& Revenue (Rp) & $3,038,000.00$ & $19,900,000.00$ \\
3 & Total revenue (Rp) & 1,000 & 500 \\
4 & Number of Chickens (head) & $33,038.00$ & $39,800.00$ \\
5 & Revenue (Rp/head) & & \\
\hline
\end{tabular}

Source: Primary Data Processed, 2020

The productivity of laying hens in the BUMDes "Mandiri" farm is 288 eggs/year and in partner farms 336 eggs/year. The productivity of laying hens in the BUMDes "Mandiri" farm is lower because the chickens are 96 weeks old while in partner farmers they are 24 weeks old. This is by the opinion of Maharani et al. (2013) in Luthfi et al. (2020) that when chickens are 22 weeks old, their productivity will increase and

reach their peak at 28-30 weeks of age. Then egg production decreases slowly to $55 \%$ after the chicken is 82 weeks old.

\section{Income}

The average revenue, total cost, and income of layer chicken farms of BUMDes "Mandiri" and breeder partners can be seen in Table 7.

Table 7. Average operating income of BUMDes "Mandiri" layer chicken farms and breeder partners in one month

\begin{tabular}{clrrrr}
\hline \multirow{2}{*}{ No } & \multirow{2}{*}{ Variables } & \multicolumn{2}{c}{ BUMDes “Mandiri” } & \multicolumn{2}{c}{ Breeder partners } \\
\cline { 3 - 6 } & & \multicolumn{1}{c}{$\mathrm{Rp}$} & \multicolumn{1}{c}{$\mathrm{Rp} / \mathrm{h}$ had } & \multicolumn{1}{c}{$\mathrm{Rp}$} & \multicolumn{1}{c}{$\mathrm{Rp} / \mathrm{head}$} \\
\hline 1 & Total Revenue & $33,038,000.00$ & $33,038.00$ & $19,900,000.00$ & $39,800.00$ \\
2 & Total Cost & $29,369,110.00$ & $29,369.11$ & $13,495,495.00$ & $26,990.99$ \\
3 & Income & $3,668,890.00$ & $3,668.89$ & $6,404,505.00$ & $12,809.00$ \\
\hline
\end{tabular}

Sumber: Primary Data Processed, 2020

The average income of BUMDes "Mandiri" is Rp. 3,668,890.00/month or Rp. $3.668,89 /$ head, and breeder partners of Rp. 6,404,505.00/month or Rp. 12,809.00/head. The partner breeder business provides a higher income than the BUMDes "Mandiri" business. In addition to chicken productivity and higher egg selling prices, breeder partners make savings on several components of business costs.

The results of research by Rakhmadevi and Wardhana (2020) in one business period (1.5 years), laying hens in Klurahan Village, Ngronggot District, Nganjuk Regency provide income for a business scale of 1,500 individuals, which is Rp. 523,455,510.00. If the income is calculated per chicken in one month, it generates an income of Rp. 19,720.57/chicken. Meanwhile, according to research by Suparno and Maharani (2017), the income from laying hens business in
Ambuten District, Sumenep Regency is higher every month, which is Rp. 24,293.73/head. The amount of income from the two studies is greater than the income from the BUMDes "Mandiri" farm business and its breeder partners because the income is also contributed by the sale of rejected chickens. Meanwhile, at BUMDes "Mandiri", at the time the research was conducted, they had not yet sold rejected chickens even though some of the chickens were classified as rejected chickens. BUMDes "Mandiri" breeder partners also do not have chickens in the rejected chicken category. In addition, the selling price is still relatively low compared to other regions.

\section{Profit-Sharing System Analysis}

The profit-sharing system between farmers and BUMDes "Mandiri" is based on the capital provided to breeder partners. BUMDes 
"Mandiri" cooperates with partner farmers so that the benefits of the establishment of BUMDes "Mandiri" can be felt by the community, especially farmers in Babakan Bogor Village, Bengkulu.

The assistance provided to farmers by BUMDes "Mandiri" is in the form of capital.
Profit-sharing is carried out from the business income obtained by breeder partners, with a proportion of $51 \%$ of the partner breeder's business income being handed over to BUMDes "Mandiri" and the remaining 49\% belonging to breeder partners (Table 8).

Table 8. Income accepted by BUMDes "Mandiri” and breeder partners from profit-sharing system

\begin{tabular}{|c|c|c|}
\hline Description & $\begin{array}{c}\text { Percentage of the income in } \\
\text { partnership }(\%)\end{array}$ & $\begin{array}{l}\text { Amount } \\
\text { (Rp/month) }\end{array}$ \\
\hline $\begin{array}{l}\text { a. Income of Breeding } \\
\text { Business Partnership }\end{array}$ & & $6,404,505.00$ \\
\hline $\begin{array}{l}\text { b. Profit-sharing portion for } \\
\text { BUMDes "Mandiri"" }\end{array}$ & 51 & $3,266,295.00$ \\
\hline $\begin{array}{l}\text { c. Profit-sharing portion for } \\
\text { breeder partners }\end{array}$ & 49 & $3,138,210.00$ \\
\hline
\end{tabular}

Source: Primary Data Processed, 2020.

The time allotted for breeder partners is 12 months from the time the agreement is signed by both parties. The income of partner laying hens is Rp. 6,404,505.00/month. Thus, based on the agreement, BUMDes "Mandiri" gets Rp $3,266,295.00 /$ month and breeder partners get a share of $\operatorname{Rp~3,138,210.00/month.~}$

The partnership system allows BUMDes "Mandiri" to also earn income from laying hens farms. The livestock business which is managed by BUMDes "Mandiri" generates an income of Rp. 3,668,890.00/month, so that in one month BUMDes "Mandiri" earns income from laying hens farming of Rp. 6,935,185.00/month.

The results of the study show that the livestock business is indeed profitable. This is in line with the statement of Rahmi et al. (2018) that layer chicken business has a positive impact from economic, social, and environmental aspects. This business can provide jobs, and is also friendly to the environment. The results of this study also provide evidence that BUMDes "Mandiri" can achieve its goals, namely improving the village economy and providing business opportunities for rural communities. According to Saputra (2017), BUMDes was established with the aim of 1) Improving the village economy, 2) Increasing village original income, 3) Improving village potential management according to community needs, and 4) Being the backbone of village economic growth and equity. Efforts to build the village economy carried out by BUMDes "Mandiri" also follow these cooperative, participatory, emancipatory, transparent, accountable, and sustainable principles. Thus, it is hoped that together with other business units, BUMDes "Mandiri" can progress, be independent and professional.

\section{CONCLUSION}

The conclusion that can be formulated from this research is that the income from the BUMDes "Mandiri" livestock business in one month is Rp. $3,668,890.00$ or Rp. 3,668.89/head while the breeder partner's income is Rp. $6,404,505.00$ or Rp. $12,809.00 /$ head. The portion of the breeder partners' income that belongs to BUMDes "Mandiri" is Rp. 3,266,295.00/month and that which belongs to breeder partners is $\mathrm{Rp}$. $3,138,210.00 /$ month.

\section{REFERENCES}

Barokah, U., W. Rahayu dan M. T. Sundari 2016. Analisis Biaya dan Pendapatan Usahatani Padi di Kabupaten Karanganyar. Jurnal AGRIC. 26 (2): 12 - 19.

https://peraturan.bpk.go.id. 2017. Peraturan Pemerintah Republik Indonesia Nomor 43 Tahun 2014 tentang Peraturan Pelaksanaan Undang-Undang Nomor 6 Tahun 2014 Tentang Desa. Diakses pada Tanggal 15 Desember 2019 Pukul 10.15 WIB. 
Luthfi, A.C, Suhardi dan E.C. Wulandari. 2020. Produktivitas Ayam Petelur Fase Layer II dengan Pemberian Pakan Free Choice Feeding. Tropical Animal Science 2 (2): 57-65.

Murib, P., I. Kurniasih dan Kadarso. 2014. Analisis Ekonomi Usaha Ayam Petelur di Farm Harma Banjarharjo Kecamatan Ngemplak, Sleman. Agros. 16 (1) : 19-29.

Nawawi, A. M., S. A. Andayani dan Dinar. 2017. Analisis Usaha Peternakan Ayam Petelur (Studi Kasus Pada Peternakan Ayam Petelur Cihaur, Maja, Majalengka, Jawa Barat). Jurnal Ilmu Pertanian dan Peternakan 5 (1): 15 - 29.

Purwaningsih, D.L. 2014. Peternakan Ayam Ras Petelur di Kota Singkawang. Jurnal Online Mahasiswa Arsitektur Universitas Tanjungpura 2 (2): 74-88.

Rahmi E., E. Khairina dan W. Sartika. 2018. Analisis Kelayakan Finansial Usaha Peternakan Ayam Ras Petelur di Kecamatan Guguak Kabupaten Lima Puluh Kota Provinsi Sumatera Barat (Studi Kasus pada Usaha Ayam Petelur Jaka Farm, Kubang Tungkek). Prosiding SEMNAS PERSEPSI III MANADO. ISBN 978-6020752-26-6 Hal: 579 - 588.
Rakhmadevi, A. G. dan D. I. Wardhana. 2020. Analisis Usaha Ayam Ras Petelur di Desa Klurahan Kecamatan Ngronggot Kabupaten Nganjuk. Jurnal AGRINIKA 4 (1): 78-91.

Saputra, R. 2017. Peranan Badan Usaha Milik Desa (BUMDes) sebagai Implementasi Ekonomi Kreatif dalam Rangka Pemberdayaan Masyarakat Desa Jalancagak Kecamatan Jalancagak Kabupaten Subang Provinsi Jawa Barat. Transformasi: Jurnal Manajemen Pemerintahan 3 (1): $15-31$.

Sari, I. P. dan R. A. Ekaputri. 2019. BUMDES di Kecamatan Kabawetan: Kajian Manfaat bagi Masyarakat. Convergence: The Journal of Economic Development 1(1) : 55-69.

Suparno dan D. Maharani. 2017. Analisis Kelayakan Usaha Peternakan Ayam Ras Petelur di Kecamatan Ambunten Kabupaten Sumenep. MADURANCH 2 (1): $31-36$.

Suratiyah, K. 2016. Ilmu Usahatani Edisi Revisi. Cetakan ke-2. Penebar Swadaya. Jakarta. 